\title{
PAUL TILLICH E A PSICOLOGIA
}

\author{
Gustavo Vieira da Silva
}

Bacharelando em Psicologia pela Universidade Federal do Paraná e Teologia pela Faculdade Teologica Batista do Paraná, Curitiba, PR - Brasil, e-mail: gustavovieira.psicologia@ gmail.com

COOPER, T. D. Paul tillich and psychology: historic and contemporary explorations in theology, psychotherapy and ethics. United States: Mercer University Press, 2006.

Terry D. Cooper é um professor norte-americano que pesquisa as interfaces entre a psicologia e a teologia. Ele leciona psicologia na St. Louis Community College e estudos religiosos na Webster University. É autor das obras Sin, pride and self-acceptance (2003) e Religious though and the modern psychologies (2004).

Nesta obra, Cooper dedica-se a explorar as relações do teólogo de tradição luterana Paul Tillich com a psicologia. Para tanto, o autor divide seu livro em seis capítulos. Nos três primeiros capítulos, aborda a articulação dos conceitos teológicos de aceitação, angústia e alienação - centrais no pensamento de Tillich - com a psicologia de meados do século XX e, ademais, com algumas tendências contemporâneas em psicologia. Na continuação, no quarto e quinto capítulos, analisa os debates do New York Psychology Group, entre 1941 e 1945, grupo no qual Tillich manteve estreito contato com prestigiados pensadores da psicologia da época. Por fim, o último capítulo trata dos desdobramentos do pensamento de Tillich no final do século XX e na atualidade.

No primeiro capítulo, Cooper analisa com profundidade o significado da aceitação no pensamento de Tillich. Este teólogo propôs uma redescoberta do significado dos termos da tradição cristã: no lugar de pecado ele sugeriu a noção de "separação" e, igualmente, para falar de graça ele utilizava a idéia de "aceitarse aceito". Neste contexto, Tillich considerou que as reflexões sobre a aceitação do paciente no campo da psicoterapia trouxeram grandes contribuições para a 
teologia no que concerne à experiência de ser aceito. Tillich considerava que Lutero fora tanto um teólogo como um precursor da psicologia profunda, pois abordava com seriedade o caráter trágico e a ambivalência de toda a realização humana - incluindo a fé. A partir desta ênfase luterana, Tillich travou uma discussão com o psicólogo Carl Rogers acerca das possibilidades de "autoaceitação". Enquanto para Rogers, haveria somente uma tendência no ser humano - a autoatualização - para Tillich a existência de uma angústia ontológica traria sempre a emergência de tendências destrutivas e de conflitos na psique. Logo, na perspectiva de Tillich, não haveria possibilidade de uma aceitação plena na esfera humana (limitada pelas condições da finitude) e, assim, somente seria possível se falar da aceitação completa quando esta se dá a partir de Deus (que suplanta as ambiguidades da finitude). A partir deste quadro, Cooper apresenta as críticas feitas por Deborah van D. Hunsinger e Don. S. Browning: aquela autora apontou para uma possível confusão no uso da linguagem teológica e psicológica na obra de Tillich e este pesquisador questionou a coerência do pensamento tillichiano ao sustentar tanto a proposição da aceitação do humano por Deus quanto uma perspectiva não-personalista do divino.

Em seguida, no segundo capítulo, Cooper faz um panorama excelente da questão da angústia na obra de Tillich. Numa pesquisa meticulosa, ele aponta tanto para as experiências de separação e guerra da vida pessoal como para a afinidade com as tendências em psicologia e filosofia do inicio do século XX como influências de Tillich que engendraram a sua noção de angústia. Para Tillich, a angústia estaria em correlação com o conceito de coragem, que em seu pensamento é elevado do patamar ético para o ontológico. $\mathrm{O}$ ser humano estaria sempre corajosamente afirmando seu ser diante de três formas de angústia: (1) destino e morte; (2) culpa e condenação; e (3) vacuidade e falta de sentido. No pensamento de Tillich a angústia não é somente um elemento da vida neurótica, mas uma categoria do próprio ser. Portanto, Tillich se opõe a toda a perspectiva de aniquilação da angústia como se esta fosse um "sintoma", criticando-as como formas impossíveis de "autossalvação". A partir desta idéia, Cooper faz uma interessante atualização das proposições de Tillich, analisando a incompatibilidade da remoção da angústia pelo tratamento cognitivo-comportamental - o atualmente mais popular nos Estados Unidos - com a idéia de angústia enquanto categoria ontológica.

No terceiro capítulo, por sua vez, Cooper apresenta com grande clareza o controvertido conceito de alienação afirmado por Tillich. Para este teólogo, apesar do fato de que a criação fora potencialmente boa, a passagem da essência 
para a existência - o processo de efetivação da liberdade finita - acarretou uma alienação total da humanidade, condição que o ser humano não pode compreender inteiramente e nem superar por si mesmo. Para Tillich, tanto a psicologia profunda (psicanálise) como o existencialismo moderno apontavam para o desespero e para o irracional na vida humana, corroborando com sua perspectiva de alienação. Confrontando a proposta de Tillich, Cooper traz três importantes críticas à noção de alienação. Reinhold Niebuhr, professor que convidou Tillich para lecionar no Union Theological Seminary, acreditava que a perspectiva tillichiana sobre a alienação acarretava grandes dificuldades, pois fazia do pecado não somente algo inevitável, mas também necessário. A teóloga feminista Judith Plaskow, por sua vez, considerava que a proposta de se vincular a queda da humanidade com a efetivação da liberdade poderia sugerir a passividade como uma virtude, o que viria a ratificar ainda mais a subjugação da mulher na sociedade. Já Erich Fromm, referenciado tanto pela psicanálise como pelo marxismo, defendia que a alienação do ser humano de si mesmo e da sociedade eram superáveis pelas vias da ciência psicológica e da organização política.

O debate entre Fromm e Tillich é extensamente abordado nos capítulos quatro e cinco, nos quais Cooper apresenta uma minuciosa e rica descrição de cada encontro do New York Psychology Group (NYPG) entre os anos de 1941 e 1945. Neste grupo participaram vários pensadores da psicologia do século XX, dentre os quais se destacam - além de Fromm e Tillich - Carl Rogers, Rollo May, Ruth Benedict, Seward Hiltner e David Roberts. Durante seus quatro anos de discussões, o NYPG abordou basicamente quatro ênfases psicológicas: fé, amor, consciência e ajuda. Segundo Cooper, os dois colaboradores mais profícuos do grupo foram Fromm e Tillich, representando dois lados nos embates realizados nos encontros do NYPG. Em todas as discussões, Fromm e a grande maioria do grupo advogavam a necessidade de se rejeitar qualquer autoridade transcendente, defendendo a fé nas capacidades da humanidade, a ética antropocêntrica e uma noção de ajuda que tencionava a uma neutralidade de valores morais. Tillich, acompanhado por May e Roberts, afirmava a relação com o incondicionado inevitável tanto para questões morais e éticas quanto para a definição da substância da fé e a natureza dos valores comunicados pelo psicoterapeuta. Além da apresentação de muitas falas dos participantes do NYPG, Cooper veicula os desdobramentos que os debates tiveram nas obras de Tillich e Fromm, compondo uma contribuição singular para os diálogos entre psicologia e religião. 
No último capítulo, Cooper dedica-se a examinar a influências de Tillich nas tendências norte-americanas contemporâneas em teologia. Segundo ele, as divergentes tendências revisionista de tradição tillichiana (teologia feita em diálogo e a partir da cultura) e pós-liberal de tradição barthiana (teologia como preservação dos conteúdos da tradição) foram aproximadas a partir da proposição de uma hermenêutica teológica crítica. Esta perspectiva, desenvolvida por David Tracy a partir da filosofia de Paul Ricoeur, advoga a impossibilidade de um conhecimento totalmente objetivo, mas defende a viabilidade de um distanciamento crítico. É neste contexto, que indica tanto para a possibilidade de interdisciplinaridade como para a necessidade de pressuposições para todo o conhecimento que, atualmente, Don S. Browning realiza suas pesquisas. Browning tem uma postura semelhante à que fora mantida por Tillich, estudando as questões relativas às concepções de natureza humana das correntes psicológicas ao examinar os seus diferentes aportes ontológicos. Concluindo, Cooper destaca como principal relevância de Tillich a concepção de que a psicologia assume invariavelmente pressuposições filosóficas e teológicas. Logo, o pensamento de Tillich traz um desafio para a teologia contemporânea em articular discussões que apontem para as questões acerca da natureza humana para além do campo da psicologia, enfocando sua relação com o transcendente e o incondicional.

A obra de Cooper é um exemplo notável das possibilidades na pesquisa interdisciplinar entre a psicologia e teologia na atualidade. Cooper organiza a obra de forma didática, elucidando com clareza os conceitos de Tillich e utilizando uma linguagem simples e precisa. As interpolações de críticas ao pensamento de Tillich por outros autores agregam detalhes ricos ao livro, porém algumas vezes interrompem o curso de desenvolvimento do texto tornando a leitura bastante difícil. Contudo, o estudo cuidadoso do pensamento de Tillich e o detalhamento sobre as atividades do New York Psychology Group tornam esta obra indispensável para todos os pesquisadores interessados no diálogo entre a psicologia e a teologia.

Recebido: 02/06/2008

Received: 06/02/2008

Aprovado: 30/06/2008

Approved: 06/30/2008 